\title{
A Bird's Eye View on Reputation Risk Measures of Mutual Fund Industry
}

\author{
G.V. Satya Sekhar \\ MBA Centre for Distance Learning, GITAM University, Third Floor, Balaji Metro Plaza, Dondaparthi Main Road, Visakhapatnam - 530 \\ 016 ,Andhra pradesh. India \\ *Corresponding Author: gudimetlavss@yahoo.com
}

Copyright (C) 2014 Horizon Research Publishing All rights reserved.

\begin{abstract}
Reputation risk is not a unique risk, it is a consequence of other risks like operational risk and other poor risk management practices. It also emerges due to lack of good capital as well as human capital management. At the same time, negative news about the organization or negative blogs created by employees leads to more damage to reputation. This paper also aims on risk management in mutual fund organizations, because they are dependent on confidence of investors. Lack of reputation and confidence leads to decline in the component of investor proportion. In this context, this paper is intended to address three issues: i) reputation risk measures, ii) risk analysis for mutual fund industry and iii) how to sustain reputation to reap long term gains.
\end{abstract}

Keywords Reputation Risk, Operational Risk, Systematic and Unsystematic Risk, Mutual Funds

\section{Introduction}

'Reputation Management' included tracking a companies' activity and online presence as well as taking into account the views that other people have about this company. 1 Reputation is the perceived impression that stake holders have about how a company is managing its business process. According to Tomasz Obloj and Krysztof Obloj 2 The smaller the difference among competitors in terms of corporate reputation, the more valuable a unit of reputation in the industry.

\section{The Reputation Equation ${ }^{3}$}

$$
\text { Reputation }=\text { experience }- \text { expectations }
$$

1 Brain Gravin, Why Reputation Risk Management is so important these days, Nov 1st, 2011

2 Tomasz Obloj and Krysztof Obloj, "Diminishing Returns from Reputation: Do Followers Have a Competitive Advantage?" Corporate Reputation Review, Vol. 9, No. 4, 2006, pp. 213-224

3 Harpur, Oonagh Mary, in Corporate Social Responsibility Monitor (2002). London : Gee Publishing, Chapter B4
Stakeholder expectations are shaped by their beliefs about what a business is and what it does. These beliefs are influenced by what the business says about itself and by what others say about it. Stakeholders then measure their actual experience of how the business acts against their expectations. A good reputation is achieved when there is congruence between a business's purpose, its goals and values (what it professes to be), its conduct and actions (what it does it practice) and the experience and expectations of its stakeholders. Harris 4 Interactive has been applying a reputation quotient methodology to rank U.S. firms with the best and worst reputations.

How significant a threat do the following risks pose to your company's global business operation today?

(index score, where 100 = highest)

Reputational risk (eg, events that undermine public trust in your products or brand):52

Regulatory risk (problems caused by new or existing regulations):41

Human capital risks (eg, skills shortages, succession issues, loss of key personnel):41

IT network risk (eg, network security breaches, IT systems failure):35

Market risk (risk that the market value of assets will fall):32

Credit risk (risk of bad debt):29

Country risk (problems of operating in a particular location): 21

Financing risk (difficulty raising finance):19

Terrorism: 18

Foreign exchange risk (risk that exchange rates may worsen): 18

Natural hazard risk (eg, hurricanes, earthquakes):18

Political risk (danger of a change of government): 18

Crime and physical security: 15

Source: Economist Intelligence Unit, 2005

4 The methodology is based on 20 corporate attributes in six categories of public expectations (financial performance, social responsibility, workplace environment, quality of products and services, vision and leadership, and emotional appeal). 


\section{Review of Literature}

Sowmya Kanthi Ghosh 5 states that reputation risk can be quantified. She explains with recent example of the Swiss bank UBS's loss of $\$ 2.3 \mathrm{bn}$. This loss was a result of unauthorized trading. Recently, operation fraud at Societe Generale. Web serve survey 6 reveals that 68 per cent of respondents said that data breaches happen when employees take confidential data with them while leaving company. However, 63 per cent of respondents opined that the ultimate responsibility of data loss should lie with the board of organization.

David Davies 7 explains that the 'Reputation Risk Management' can only be effective if it operates holistically - not as a specialist function to be activated in an emergency but as a major influence on the organisation's actions, behaviour and standards. However, the organisations that apply universally high standards run the risk of becoming bogged down by cost or debilitating rules. The key is to understand your reputation - it is in all probability your biggest asset - and match its management to its needs. If done properly, a well-executed Reputation Risk Management exercise will have spin-off benefits that can, by themselves, massively improve corporate performance and profitability.

Daniel Diermeier 8 states that reputational damage can hurt a company in many ways. Take the example of Wal-mart. Over the last two years, Wal-mart has been the subject of negative news coverage on topics ranging from environmental and labor concerns to allegations that Wal-mart has negative net effect on local communities. These accusations (whether true or false) have already had an impact on Wal-mart's business performance.

Stelios C. Zyglidopoulos etal. 9, study states that the corporate reputation can assist firms engaging in acquisitions and internationalization efforts.

Shally Venugopal, Clay Rigdon, Florence Daviet 10 mentioned that : besides stakeholders' requests for environmental stewardship, financial institutions are starting to realize that to manage risk better, they should consider climate change in their business decisions. Goldman Sachs (GS), for example, through its GS Sustain strategy, is identifying investment opportunities by considering environmental (among other) criteria across a broad range of industries. Meanwhile, numerous pension funds in Europe and the United States are starting to assess investment risk through the lens of climate change. Particularly under an

\footnotetext{
5 Sowmya Kanthi Gosh, Measures of reputation risk, Dec 8th 2011, Financial Express.

${ }^{6}$ Web Serve survey results published in 'Xotoday', date April 14th, 2010

7 David Davies , Reputation Risk Management - a Holistic Approach, www.idrisk.com

8 Daniel Diermeier, Measuring and Managing Reputational Risk, Risk

Management, March 2008 - Issue 12
Stelios C. Zyglidopoulos, Richard DeMartino, and David McHardy Reid, "Reputation as a Facilitator in the Internationalization of Small and Medium-Sized Enterprises," Corporate Reputation Review, Vol. 9, No. 1, pp

$79-87$.
${ }^{10}$ Shally Venugopal, Clay Rigdon, Florence Daviet, Accounting for Risk: Conceptualizing a Robust Greenhouse Gas Inventory for Financial Institutionsm World Resources Institute, New Bulletin, Aug, 2009.
}

environment-focused policy era in the United States and globally, climate risk assessments may soon become part of a financial institution's fiduciary duty to their clients and shareholders.

Jan Bebbington, Carlos Larrinaga, Jose M. Moneva 11 study is to explore the proposition that corporate social responsibility reporting could be viewed as both an outcome of, and part of reputation risk management processes. They find that the concept of reputation risk management could assist in the understanding of corporate social responsibility reporting practice.

A recent study by shedan 12 interesting light on a five stage process stressing for brands attributes similar to those described here for reputation i.e. differentiation, positioning, personality, vision and added value.

\section{Reputation Risk Measures in Mutual Fund Industry:}

Jensen Model: The measure of portfolio performance summarized below is derived from a direct application of the theoretical results of the capital asset pricing models derived independently by Sharpe (1964), Lintner (1965a) and Treynor.

All three models are based on the assumption that (1) all investors are averse to risk, and are single period expected utility of terminal wealth maximizers, (2) all investors have identical decision horizons and homogeneous expectations regarding investment opportunities, (3) all investors are able to choose among portfolios solely on the basis of expected returns and variance of returns, (4) all trans-actions costs and taxes are zero, and (5) all assets are infinitely divisible. Given the additional assumption that the capital market is in equilibrium, all three models yield the following expression for the expected one period return on any security (or portfolio) $j$ :

$$
\mathrm{E}\left(R_{j}\right)=R F+\beta_{\mathrm{J}}\left[\mathrm{E}\left(R_{m}\right)-R F\right]
$$

where the tildes denote random variables, and $\mathrm{RF}=$ the one-period risk free interest rate.

$\beta J=\operatorname{cov}(j \mathrm{RJ}, \mathrm{RM}) / \sigma 2 \mathrm{RM}=$ the measure of risk (hereafter called systematic risk) which the asset pricing model implies is crucial in determining the prices of risky assets.

$\mathrm{E}(\mathrm{RM})=$ the expected one-period return on the "market portfolio" which consists of an investment in each asset in the market in proportion to its fraction of the total value of all assets in the market. Thus eq. (1) implies that the expected return on any asset is equal to the risk free rate plus a risk premium given by the product of the systematic risk of the asset and the risk premium on the market portfolio.

The risk premium on the market portfolio is the difference between the expected returns on the market portfolio and the risk free rate. Equation (1) then simply tells us what any

\footnotetext{
11 Jan Bebbington, Carlos Larrinaga, Jose M. Moneva, (2008),"Corporate social reporting and reputation risk

management", Accounting, Auditing \& Accountability Journal, Vol. 21 Iss: 3 pp. $337-361$

${ }_{12}$ Leslie de Chernatony, "Towards the Holy Grail of Defining brand", Marketing Theory, vol. 9, $\mathrm{n}^{\circ} 1$ - May 2009
} 
security (or portfolio) can be expected to earn given its level of systematic risk, $\beta J$. If a portfolio manager or security analyst is able to predict future security prices he will be able to earn higher returns than those implied by eq. (1) and the riskiness of his portfolio. We now wish to show how (1) can be adapted and extended to provide an estimate of the forecasting ability of any portfolio manager. Note that (1) is stated in terms of the expected returns on any security or portfolio $j$ and the expected returns on the market portfolio. Since these expectations are strictly unobservable we wish to show how (1) can be recast in terms of the objectively measurable realizations of returns on any portfolio $j$ and the market portfolio $\mathrm{M}$.

Fama Model: In Fama's decomposition performance evaluation measure of portfolio, overall performance can be attributed to selectivity and risk. The performance due to selectivity is decomposed into net selectivity and diversification. The difference between actual return and risk-free return indicates overall performance:

$$
\mathrm{Rp}-\mathrm{Rf}
$$

Where in

$\mathrm{Rp}$ : is actually return on the portfolio, which is monthly average return of fund.

Rf- is monthly average return on treasury bills 91-days.

The overall performance further can be bifurcated into performance due to selectivity and risk. Thus,

$$
R p-R f=[R p-R p(\beta p)+R p(\beta p)-R f)]
$$

In other words, Overall performance $=$ selectivity + risk

\section{Treynor and Mazuy Model}

Treynor and Mazuy developed a prudent and exclusive model to measure investment managers' market timing abilities. This formulation is obtained by adding squared extra return in the excess return version of the capital asset pricing model as given below:

$$
\left(\mathrm{R}_{\mathrm{pt}}-\mathrm{R}_{\mathrm{ft}}\right)=\alpha+\beta \mathrm{p}\left(\mathrm{R}_{\mathrm{mt}}-\mathrm{R}_{\mathrm{ft}}\right)+\mathrm{yp}\left(\mathrm{R}_{\mathrm{mt}}-\mathrm{R}_{\mathrm{ft}}\right)^{2+} \mathrm{e}_{\mathrm{pt}}
$$

Where

$\mathrm{Rpt}$ - is monthly return on the fund

Rft- is monthly return on 91 days treasury bills

Rmt- is monthly return on market index

Ept is error term

This model involves running a regression with excess investment return as dependent variable and the excess market return and squared excess market return as independent variables. The value of coefficient of squared excess return acts as a measure of market timing abilities that has been tested for significance of using t-test. Significant and positive values provide evidence in support of the investment manager's successful market timing abilities.

Statman Model: Statman measured mutual funds using the following equation:

eSDAR ( excess standard deviation and adjusted return) $=$ $\mathrm{Rf}+(\mathrm{Rp}-\mathrm{Rf})(\mathrm{Sm} / \mathrm{Sp})-\mathrm{Rm}$

Rf- monthly return on three-month treasury bills

$\mathrm{Rp}-$ monthly return on fund portfolio
$\mathrm{Rm}$ - monthly return on the benchmark index

Sp- standard deviation of portfolio p's return and

$\mathrm{Sm}$ - standard deviation of return on the bench mark index.

\section{Relative Performance Measure- Choi Model}

Choi provides a theoretical foundation for an alternative portfolio performance measure that is incentive-compatible. In this model, a risk-averse portfolio manager is delegated to manage a fund, and his portfolio construction (and information-gathering) effort is not directly observable to investors. The fund manager is paid on the basis of the portfolio return that is a function of effort, managerial skill, and organizational factors. Choi assumes that a unit of managerial effort produces the same amount of private information for all managers. However, they are assumed to differ in performance because of heterogeneous skills in utilizing the same amount of information. The organizational factor is inherent in fund companies and influences the portfolio return but is beyond the manager's control. The institutional (organizational) factor is broadly interpreted to capture any factors that affect the fund's total return as a result of institutional elements. Incentive contracts can be considered as one of those factors. Inefficient incentive contracting, explicit or implicit, discourages fund managers from exerting appropriate efforts. Economies of scale are another example. The cost of managerial effort may depend on the size of the funds. Thus the scale factor may affect managerial incentive and thus the total fund return. To the extent that these institutional factors exist, an efficient performance evaluation system should isolate these factors in evaluating a manager's performance.

In this model, the effect of institutional factors is described by the incentive contractual form and disutility (or cost) function of managerial efforts in fund operations. It focuses on the cost function as an organizational factor (simply, scale factor). It was assumed that the disutility function of each fund is determined by the unique nature of its operation (e.g., fund size) and is an increasing function of managerial effort at an increasing rate. For example, owing to a scale factor, the cost function of a larger fund may be a flatter. This assumption is meant to be just one of many plausible assumptions and is not required in the model. It is probable that the costs of gathering information and managerial skills may be interrelated. curve than that of a smaller fund. Thus the marginal cost for the larger fund will be smaller at the same level of effort. Alternatively, a manager for the larger fund can exert more effort at the same cost. This implies that it is possible for a manager with an identical skill to perform poorly for a small fund merely because diseconomies of scale in the fund force the manager to exert less effort, resulting in less amounts of private information. Therefore, in order not to penalize the manager for poor performance due to uncontrollable diseconomies in his operation, the scale factor should be accounted for in an incentive-compatible evaluation scheme. Relative performance evaluation is shown to be a part of the 
alternative performance index derived from the Grinblatt and Titman (1989) argue that there may exist economies of scale in the mutual fund industry, probably arising from the size of individual funds. There is a very limited amount of study in this area. Exceptions are Ferris and Chance (1987) and Dermine and Roller (1992). Ferris and Chance found a negative relationship between expense ratios and sizes of funds in a regression analysis, indicating the existence of economies of scale in mutual funds. However, using French mutual fund data, Dermine and Roller showed that there may exist economies (diseconomies) of scale for small (large) funds. Grinblatt and Titman (1989) point out that transaction costs such as expense ratios are good surrogates for a manager's private information, because if portfolio managers have superior information or ability, they may be able to expropriate the economic rents by charging higher fees.

Reputational challenges can emerge from any area of day-to-day decision making. But executives tend to make decisions without consideration for the reputational impact. Their key skill is the ability to maintain an external perspective throughout the decision-making processes and incorporate this perspective into the design of the business decision, e.g., the launch of a new product and its market-entry strategy.

\section{Conclusion}

Management of reputation risk is the need of the hour for every organization. There is no exception to this even for mutual fund organizations. Hence, the AMCs should understand the various methods and techniques of reputation risk management and they should try to adopt recent techniques to maintain reputation and avoid risk for gaining investor's confidence. Mutual fund organizations need to understand their decisions create a record today that will serve as the basis for their story tomorrow. Assessing reputational risk requires anticipating what a reputational crisis will look like and then taking proactive steps to prevent and prepare.

\section{REFERENCES}

[1] Brain Gravin, Why Reputation Risk Management is so important these days, Nov $1^{\text {st }}, 2011$

[2] Harpur, Oonagh Mary, in Corporate Social Responsibility Monitor (2002). London : Gee Publishing, Chapter B4

[3] Sowmya Kanthi Gosh, Measures of reputation risk, Dec $8^{\text {th }}$ 2011, Financial Express.

[4] Web Serve survey results published in 'Xotoday', date April $14^{\text {th }}, 2010$

[5] David Davies , Reputation Risk Management - a Holistic Approach, www.idrisk.com
[6] Shally Venugopal, Clay Rigdon, Florence Daviet, Accounting for Risk: Conceptualizing a Robust Greenhouse Gas Inventory for Financial Institutionsm World Resources Institute, New Bulletin, Aug, 2009.

[7] Jan Bebbington, Carlos Larrinaga, Jose M. Moneva, (2008),"Corporate social reporting and reputation risk management", Accounting, Auditing \& Accountability Journal, Vol. 21 Iss: 3 pp. 337 - 361

[8] Leslie de Chernatony, "Towards the Holy Grail of Defining brand", Marketing Theory, vol. 9, $\mathrm{n}^{\circ} 1$ - May 2009.

[9] Daniel Diermeier, Measuring and Managing Reputational Risk, Risk Management, March 2008 - Issue 12, pp 20-24

[10] Gupta, L.C., 'Mutual Funds and Assets Preference', Society for Capital Market Research and Development, New Delhi, 1993.

[11] La Porta, R., Lopez-de-Silanes, F., Shleifer, A. and Vishny, R. W. (2000), "Investor Protection and Corporate Governance", Journal of Financial Economics, Vol.58, pp:3-27.

[12] Lavington, Frederick, The English Capital Market, London: Metheren, 1921.

[13] Levine, R. (1999), "Foreign Bank Entry and Capital Control Liberalization: Effects on Growth and Stability", University of Minnesota, mimeo.

[14] Macey, J. R. and O'Hara, M. (2001) "The Corporate Governance of Banks", Federal Reserve Bank of New York Economic Policy Review.

[15] Madan Goyal, 'Mutual Funds: India, here we Come', - A Paper Published in Financial Institutions and Economic Development (Trends in Indian Economy-vol 5), Edited by Devendra Thakur, Deep \& Deep publications, New Delhi, 1993.

[16] Manish Bansal, "Mutual Funds: Eight steps to Nirvana', Chartered Financial Analyst, December, 2003.

[17] Manish Khanduri \& Surendar, 'US-64: Pandora's Box Opens', Business world $6^{\text {th }}$ August, 2001.

[18] Neeraj Choksi and Jignesh Desai, “ Mutual Funds: Safer Investments, CFA- April, 2004.

[19] Oman, C. P. (2001), "Corporate Governance and National Development”, OECD Development Centre Technical Papers, Number 180.

[20] Peek, J. and Rosengren, E. (2000), "Implications of the Globalization of the Banking Sector: The Latin American Experience", New England Economic Review, Sept./Oct., pp.45-62.

[21] Shleifer, A. and Vishny, R. (1997), "A Survey of Corporate Governance”, Journal of Finance, Vol.52, pp: 737-783.

[22] Stiglitz, J. E. (1994), 'The Role of the State in Financial Markets', Proceedings of the World Bank Annual Conference on Development Economics 1993, pp.19-52. 